\title{
ABORDAGEM CLÍNICA DO PRIMEIRO MOLAR PERMANENTE EM ODONTOPEDIATRIA
}

Priscila Cercal Rodrigues de LIMA; Natália Garcia RAFAGNIN; José Vitor Nogara Borgers de MENEZES.

O primeiro molar permanente irrompe por volta dos seis anos de idade. É o dente com maior valor estratégico na fase de transição da dentição decídua para a permanente, pois serve como guia de oclusão para todos os outros dentes que aparecerão na criança na seqüência de sua vida. Isto posto, torna-se de extrema importância que, a partir dos primeiros sinais clínicos de sua irrupção, este dente seja prioritário dentro do planejamento clínico odontopediátrico. Este trabalho tem como principal objetivo mostrar como definir os tipos de abordagens que podem ser realizadas para a manutenção da higidez deste dente, desde a definição de estratégias educativas e preventivas até o uso de vernizes fluoretados, selantes ionoméricos e resinosos. Serão apresentados casos clínicos mostrando a seqüência clínica de algumas destas propostas de intervenção. 